TURIZAM

Volume 13

Issue 2, 75-83 (2009)

\title{
Ecological and Tourist Potential of Central Belgrade
}

\author{
Nebojša Anastasijević* \\ Vesna Anastasijević* \\ Aleksandar Bobić* \\ Nadežda Stojanović* \\ Mirjana Mešiček*
}

Received: June 2009| Accepted: November 2009

\section{Abstract}

Urban green spaces traditionally represent areas where tourists gladly pause and rest. Ecological potential of green spaces, their capacity to enhance urban life through micro-climate mitigation, and their original attractiveness, represent the source from which their tourist potential is derived. Consequently, continuous increase in plant quantity and constant expansion of their existence to greenless zones and territories, commonly defined as gray or gray-green zones, is compulsory.

Green spaces of central part of old Belgrade situated on the right banks of the rivers Sava and Danube are by all criteria in the category of top tourist rank, and the same goes for this whole area with numerous attractive points within. However, this zone - the territory of three central urban municipalities (Savski Venac, Stari Grad, and Vračar) - holds numerous neglected spaces, deserted corridors and backyards, river bank segments and other sites covered with weed, debris left from past and recent bombardments, parking lots and half-devastated green stripes along residential blocks. Starting with the assumption that many of these can be qualitatively renewed and professionally greenscaped, paper describes their proper development into different categories of green spaces, important structural elements of Belgrade green infrastructure.

Key words: Ecology, Tourism, Central Belgrade, Green Infrastructure

* Department for Landscape Architecture, Faculty of Forestry, University in Belgrade, Kneza Višeslava 1, 11000 Belgrade; Serbia

- Corresponding author: nebojsa.anastasijevic@sfb.rs 


\section{Introduction}

It is well known that urban green spaces represent the most valuable part of urban open space from ecological point of view (Anastasijević, Vratuša, 1998). At the same time, these are often the most beautiful, and in psychological sense the most agreeable areas of the city. It is no wonder that tourists who visit cities round the world out of their own curiosity gladly choose these places to pause and rest, remember them for a long time, and reminisce about with their friends (Fennell, 1999). Also, there is nothing unusual in saying that these most various categories of so-called "green infrastructure", different forms and types of green and "semi-green" urban spaces, whether they are formally treated as park areas or just represent open spaces partially filled with plants, posses distinct tourist potential, particular tourist capacity which may always be enhanced by proper methods and actions (Cebailos-Lascurain, 1991).

Old urban core of Belgrade possesses exceptionally high tourist capacity since it holds, like numerous central parts of old cities round the world, the most significant historical, architectural and spatial elements that attract domestic and foreign tourists. The most important national museums, theaters, architectural achievements and monuments of the past (which by themselves represent exceptional, topmost value) are situated in the very center of Belgrade, and are probably the exact reason why it is one of the most visited places in Serbia. Numerous tourist groups from hinterland (customarily pupils from elementary and high schools), surrounding countries ("Yugo-nostalgists" as well as quite young people), and western states, most willingly spend a long time at Belgrade center in particular, where they become familiar with its past, culture and specificities of its people, relax during afternoon break or assemble before departure, establishing new or completing old impressions of our capital, and by that and to a certain extent, of a nation as a whole. In this spatially rather small zone which citizens of Belgrade traditionally call "Krug Dvojke" "The Circle of No. 2", after old tram line that has been circling the city's centre in both directions for decades), there are some of the most significant urban green spaces relatively well managed, and thus without sizable interventions suitable for receiving visitors from all over. In the first place such are Kalemegdan Park, Pionirski Park and Tašmajdan Park, together with several open and still not quite finalized spaces of great potential that makes them very interesting for all visitors. Among them the most important are Sava Pier, Terazijski Park and Academic Park. Finally, in the very center of Belgrade there are the most significant and the most beautiful street tree lines for which this city has been famous throughout the century, though some old and dilapidated, some newly reconstructed. Such are in Kralja Aleksandra Boulevard, Nemanjina St., Kralja Milana St., Kneza Miloša St., or Cara Dušana St. Also, one must not forget some of the oldest individual tree specimens in public green spaces of the city: the oldest living being in Belgrade area, 250 years old Oak tree in Cvetni trg ("Flower Square"); 110 years old Linden tree in Makedonska St., or 90 years old Plane trees along the boundaries of "Krug Dvojke" that fringe the very heart of Belgrade (Anastasijević, Vratuša, 1999). All of these make the central area of the city praiseworthy. It is the zone of topmost tourist interest, and various sightseeing tours of numerous points of interest within can be very rewarding.

There is no doubt that green spaces of a city such as Belgrade are by themselves valuable tourist destinations. This may be tested through equally logical set of criteria as ones that treat urban green as "sites in between", regarding them as incidental rest points suitably positioned between two attractive tourist sites, furnished with beneficial accompanying materials that provide shade, coolness and calm. Elemental confirmation of this statement may be found in comparison of Belgrade parks with well-known landscape and tourist values of Schenbrun 
(Vienna), Hyde Park (London), Tivoli (Ljubljana) or Margitsziget (Budapest). Thus, it is rational to consider all the necessary planning, technological and economic means that would enhance tourist value of already established green spaces, and at the same time enable zones with similar potentials - so-called gray and gray-green elements of "green infrastructure" - to improve and associate with already attractive green spaces of city's centre, the ones with stated extraordinary tourist function. One of the important tasks in that process is recognition of the most significant green spaces of Belgrade centre and impartial assessment of their genuine tourist potential.

\section{Material and Method}

Standard green space of urban area - park, square, river bank, sports or recreation zone, etc. is defined as open space within urban tissue in which plants (main structural elements) combine with abiotic elements (additional structural elements) in order to achieve topmost ecological and aesthetic effect. A number of such spaces within one limited area or the whole of the city form so-called system of urban green, while all urban spaces carrying plant or other environmental friendly material are regarded as specific net of open, undeveloped sites, known in contemporary civil planning as green infrastructure.

When defining ecological functions of large cities' urban green, the most attention should be paid to that approximately half-year period commonly known as vegetation season, particularly to the summer. In this most favorable period for tourist tours round the large city, urban green infrastructure plants provide spatial micro-climatic corrections (mitigation of high daily temperature, wind velocity, air pollution level and urban noise). Even when there are no leaves in crowns of deciduous trees (from November to April on northern hemisphere), green spaces may still distinctly contribute to quality of surroundings. Numerous protective functions of plant organisms are in effect even then, though on a lower level. That fact builds up significant part of overall tourist potential of urban green, which theoretically may be regarded as general level of positive, beneficial effect on the environment, the one which tourists may sense directly during their visit. Of course, this potential will be best observed when particular protection of visitors is needed (too much insolation, strong wind, dry air, dust, exhaust gases, unpleasant reflexes from smooth and shiny surfaces, moderate rain). Moreover, tourist capacity of urban green extends also to aesthetic values of each singular green space and its constitutional elements (the reason why all present plant individuals must be in excellent health, high condition and properly maintained), as well as to historical, cultural and psychological characteristics of urban green (apparent only if comprised of that area's domestic, specific species). It also necessitates informing visitors about all attractive facts in regard to specificities of particular spatial segments with which tourist come in direct visual contact, through functional information billboards and capable and educated tourist guides (Anastasijević, Vratuša, 2001). Finally, it is not hard to conclude that tourist capacity of urban green infrastructure in fact means all the specifics of green zones that provide their optimal, high functionality.

There are several significant open spaces of classical type and a number of smaller or larger open, semi-developed spaces which may easily be converted into new urban green spaces with distinct eco-aesthetic and tourist functions within so-called "Krug Dvojke". In the course of this research all of them were regarded as elements of sole green infrastructure of central Belgrade. Their determination was initially carried out through preliminary analysis of accessible satellite and aerial photos, followed by complete field work concerning their separate eval- 
uation. Quality and functionality analysis of plant material was conducted through customary scientific methods and techniques, applied to assessment and analysis of other green space elements as well. Tourist value of each green or semi-green space was based upon mean value of its ecological, aesthetic and cultural function. It should be pointed out that only spaces and areas already on traditional sightseeing tours of the city were investigated. Evaluation was carried out in accord with standard methodology used in landscape assessment of urban spaces (Anastasijević, 200o), expressed through multiparty grades from 1 - poor to 5 - excellent, for all evaluated features ( 1 - poor, 2 - satisfactory, 3 - good, 4 - very good, 5 - excellent).

After establishing immediate tourist values and possibilities of their enhancement for the most important elements of green infrastructure, an initial prospect appraisal for establishing new noteworthy "tourist spots" within public green of central Belgrade was carried out. It was done in accord with ecological worth of public green and management tradition in urban surroundings. Also, an assessment of effective linkage of green infrastructure central elements with suburban and out-of-city segments was made. Its aim was to provide more effective and more attractive tourist movement throughout the capital with continual green belts and zones along the main Belgrade tourist routes.

\section{Results and Discussion}

Central part of Belgrade, the area known as "Krug Dvojke", represents geographical center of the city - Terazije - and its immediate surroundings, on top of so-called Terazije reef. It is relatively regular circle around the city center, with rim defined by wide streets and very busy urban and suburban traffic. One side of this circle stretches all the way down to the bank of the river Sava, probably the most attractive part of central Belgrade, interfacing Sava Pier, the terminal of tourist ships from the Upper Danube Basin and cities down the river. Within the "Krug Dvojke" or immediately by its rim there are some of the most important city and state institutions and cultural edifices and monuments. Such are the Serbian Parliament, the Presidency, buildings of the Republic and City Government, the National Museum and specialized museum institutions, buildings of three the most important city theatres, several large faculties of the State University. Also, there are the most significant achievements of contemporary and classical architecture, attractive new and old hotels, countless restaurants and cafés. Finally, there are the most important and most attractive elements of Belgrade green infrastructure: its large and significant parks. These often represent complex structures of substantial ecological and cultural significance. Among them one should point out the green of the Kalemegdan Park, Tašmajdan Park, Pionirski Park, Academic park, Ćirilo and Metodije Park, Manjež Park, Nikola Pašić Square, Republic Square and Financial Park. Equally attractive are green spaces around several important buildings such as the Serbian Parliament or the House of Army. There is a number of churchyards (the Voznesenjska Church, the Cathedral Church, the Church of St. Alexander Nevsky, the Church of St Mark), as well as green spaces in front of and around the former State Union Parliament, those between the Old and New Royal Courts in the center of the city, new green space on Slavija Square, the ones in front of the 'Palace" Hotel and the demolished building that housed military headquarters of former Yugoslav army. Also, there are several quite valuable street tree lines and green stripes in Knez-Mihajlova St., Kralja Milana St., Nemanjina St., Kneza Miloša St., Kralja Aleksandra Boulevard, Terazije, Cara Dušana St., Džordža Vašingtona St., and Skadarska St. One must not forget several zones within central city area which may only be considered as potential green spaces, due to 
too few or erroneously arranged plants and neglected space in general. Nevertheless, they do represent elements of green infrastructure, regardless of their at the moment predominantly "grey-green" or "gray" basic character. From tourist viewpoint, the most significant and potentially most valuable among them is already mentioned Sava Pier in Karadjordjeva St., location attractive by itself due to numerous civil engineering, urbanistic and historic edifices interesting to both domestic and foreign visitor. There is also Terazije Park, neglected and devastated green space in the very heart of Belgrade, with first-class visual potential and probably the most attractive panorama of the Panonnian plane and New Belgrade, interesting for both high level of urbanization and several supreme large old trees from the first decades of the last century. Also potentially significant is the park by the Faculty of Economics, attractive green space occupied by ugly transferable parking construction on one side, and usurped by gross fence on the other, placing the very Faculty in a kind of visual ghetto. Then, there is unattended green space in front of Branko's Bridge, where high visual, historic and cultural potential may be easily and swiftly transformed into very attractive resting point on tourist route from old to new Belgrade through proper greenscaping.

The most important green infrastructural units of researched central part of Belgrade area were evaluated from of ecological, aesthetic, and historic/cultural functions/values point of view, as shown in Table 1.

In general, classic parks within the "Krug Dvojke" vary considerably in size and structure. There is only one true park in this whole zone (Tašmajdan, around 8 hectares), while all other formal green spaces may be regarded as square green, small parks, or urban blocks green. Classical green spaces of this area are as follows: Tašmajdan, Pionirski Park, Manjež Park, Academic Park, Park by Branko's Bridge, Park by 'Palas' Hotel, Park by House of Army, Terazije Park, Park by Faculty of Economics, Financial Park, Park by House of Parliament, Slavija Park and square green (Nikola Pašić and Republic Square). Among them none is completely reconstructed (moreover, Slavija Park is a completely new green space), but some are in much better shape than some time ago. New green spaces (as Slavija Park) are in good aesthetic condition, while acceptable professional management maintains visual functionality of Pionirski Park (especially the part between the Old and New Royal Courts), former Royal Gardens, and Manjež Park. Nevertheless, neither these nor other green spaces of the area receive adequate attention when historic, cultural or biological details are concerned, even though they could be of considerable tourist interest. It is important to highlight in touristically acceptable way (by attractive billboards with maps, sketches and old photographs or reconstructions) significant sites in the area: geographic specificities at the locality of former stone mine (Tašmajdan Park); location were Obrenović Dynasty seized to exist (assassination site of Aleksandar Obrenović and Draga Mašin - The Palace Garden); the site of the first accompanying civil engineering constructions for Serbian cavalry (Manjež Park); graphics of former Grand Market (Academic Park); resting platform by the first promenade of old Belgrade in Kneza Miloša St. (Financial Park); description, reconstruction and adequate graphic presentation of long ago destroyed Varoš Gate, one of great gates that were the means of communication through the fortress walls of Ottoman Belgrade (Park by Branko's Bridge); plan and realization of "wreath of alleys and parks" based on the idea of first Serbian civil planner Emilijan Josimović (never carried to the end unfortunately - Park by the 'Palas' Hotel); park foundation on a landfill (Mitić Hole on Slavija Sq.), etc.

The exceptional importance of this zone's classical green spaces (apparently not solely of ecological, but also general cultural character), may be enhanced simply by improving the state of the existing plants. Involved procedures will produce desired results much sooner and more efficiently than extensive reconstruction of civil engineering artifacts of a park - paths, 
Table 1. Evaluation of main green infrastructure units within "Krug Dvojke" in central part of Belgrade.

\begin{tabular}{|c|c|c|c|c|}
\hline $\begin{array}{l}\text { Researched green space - green } \\
\text { infrastructure unit }\end{array}$ & Ecological value & $\begin{array}{c}\text { Aesthetic/ } \\
\text { psychological value }\end{array}$ & $\begin{array}{l}\text { Geographical/ } \\
\text { historic value }\end{array}$ & $\begin{array}{l}\text { Tourist value } \\
(b+c+d) / 3\end{array}$ \\
\hline a & b & c & d & e \\
\hline Tašmajdan Park & 5 & 4 & 4 & 4,33 \\
\hline Pionirski Park & 5 & 5 & 5 & 5,00 \\
\hline Manjež Park & 4 & 5 & 3 & 4,00 \\
\hline Academic Park & 2 & 5 & 5 & 4,00 \\
\hline Park by the Branko's Bridge & 2 & 2 & 4 & 2,66 \\
\hline Park by the 'Palas' Hotel & 3 & 3 & 4 & 3,33 \\
\hline Square by the House of Army & 2 & 3 & 3 & 2,66 \\
\hline Terazije Park & 2 & 5 & 5 & 4,00 \\
\hline Park by the Faculty of Economics & 3 & 2 & 3 & 2,66 \\
\hline Financial Park & 5 & 4 & 5 & 4,66 \\
\hline Park by the Parliament of Serbia & 3 & 5 & 5 & 4,33 \\
\hline Park on Slavija Sq. & 5 & 5 & 3 & 4,33 \\
\hline Nikole Pašića Sq. & 5 & 5 & 3 & 4,33 \\
\hline Republic Sq. & 2 & 4 & 4 & 3,33 \\
\hline Cathedral Church churchyard & 2 & 5 & 5 & 4,00 \\
\hline Palace of Princess Ljubica & 4 & 5 & 5 & 4,66 \\
\hline $\begin{array}{l}\text { Churchyard of the Voznesenjska } \\
\text { Church }\end{array}$ & 5 & 5 & 4 & 4,66 \\
\hline Press Sq. & 5 & 5 & 5 & 5,00 \\
\hline Kopitareva Gradina St. & 2 & 4 & 3 & 3,00 \\
\hline Sava Peer & 3 & 5 & 5 & 4,33 \\
\hline Knez-Mihajlova St. & 5 & 5 & 4 & 4,66 \\
\hline Flower Sq. & 3 & 5 & 5 & 4,33 \\
\hline Skadarlija St. & 3 & 5 & 5 & 4,33 \\
\hline Kneza Miloša St. & 5 & 4 & 5 & 4,66 \\
\hline
\end{tabular}

plateaus, benches or sidewalls. Numerous serious defects and deficiencies of civil engineering character may be concealed much easier by skillful greenscaping, due to the fact that largescale building operations involve use of specific materials that relate to green space's establishing period, the ones seldom manufactured and hard to find nowadays. On the other hand, even simple turfing carried out with symbolic financial means may raise visual and thus tourist value to an amazing level. This is best evidenced on Slavija Sq., where conversion of landfill into low-cost green space produced an interesting resting place, an area small in size but of great psychological significance and aesthetic quality. This is the place where tourists gladly pause and with less distress browse over otherwise gloomy part of the city that completely reflects adversities of the past century in Belgrade. Equally good example is the location of destroyed National Library that underwent fascists' destruction at the beginning of World War II. Also, one must not forget former quite reduced and demoted greening of central city squares. Up to recently most of them served as large and ugly parking lots in the centre of the city, but today they are true adornments of the capital. 
Research area holds other significant elements of green infrastructure beside parks; small green oases located on numerous spots within the "Krug Dvojke", in front of governmental, cultural, educational or hotel industry structures. All of these are small green spaces, predominantly of visual quality that effectively amends architectural values of surrounding objects. Such are green spaces of the Cathedral Church, the Palace of Princess Ljubica, Andrićev Wreath, Press Sq., and the Radio Belgrade. Former representative and today devastated green space in front of the Army Headquarters Buildings destroyed in 1999, green space in front of Republic Parliament in the main city street, or Kopitareva Gradina green are also in this category, as well as neglected but very attractive green zone along Sava Pier in Karadjordjeva St. Finally, one should not forget exceptional ecological (especially in summer months), aesthetic and historic values of several most important street tree lines and solitary old trees on pavements and expansions of central city streets. The most important among them are old street tree lines in Kralja Alekandra Boulevard., Kneza Miloša St., Francuska St., Makedonska St., Gospodar Jevremova St., Resavska St., Njegoševa St., Simina St., Hilandarska St., and Skadarska St. Specific value may also be attributed to the newly founded street tree lines, installed in accord with most contemporary models of urban greenscaping. Among them the most successful are those in Kralja Milana St., and Nemanjina St. Within the street landscape, which is perhaps the most important in short tourist tour around the large city when attention is paid only to gaining the most general impression of urbanistic and overall visual character of the settlement, stands out the exceptional value of street green segments in form of street tree line fragments in Knez Mihajlova St., as well as attractiveness of individual specimens, especially if they are large, well developed, of interesting morphology, old age or at most significant site. There are several exemplary specimens: the oldest living being of Belgrade, 250 years old Oak tree (Quercus pedunculata), the last of autochthonic tree individuals that were the main feature of Šmadija region for centuries, situated within small green oasis on Flower Sq., at the intersection of Kralja Milana St. and Njegoševa St.; old London Plane trees (Platanus x acerifolia) on Press Sq.; the oldest Belgrade street tree line individual, old linden tree (Tilia hybrida) infront of 'Politika' Building; individual street trees in street tree lines and their fragments in Kralja Aleksandra Bld., Cara Dušana St., Strahinjića Bana St., Kraljice Natalije St., and several other locations of the research area. The one thing that makes up the special quality and actual value of all green spaces mentioned, whether of classical, open space (just partly or informally greenscaped) or individual valuable specimen type within the "Krug Dvojke" is the fact that they are often positioned on the course of most frequent and most attractive tourist routes that have been diligently toured by tourist groups, large (as was usually the case up to recently) or small (composed of formally targeted interest groups, as is usually done nowadays), with the same interest, trying to grasp the specificity of this soil and this city (Vratusha, Anastasijevic, 2003). In this fact, besides general knowledge of ecological, aesthetic and psychological functions of urban green, lies their additional tourist value and tourist significance. Very important among them are the green spaces of the Cathedral Church, the Palace of Princess Ljubica, decorative green of Knez Mihajlova St., Academic Park infront of the Rector's Office Building, Park near 'Palas' Hotel. Equally important are green spaces of urban squares and streets such as Republic Sq., Terazije street tree lines, Nikole Pašića Sq., Pioneer Park, the House of Parliament, Tašmajdan Park, Manjež Park, Flower Sq., street tree lines of Skadarska St., Kralja Milana St., Kralja Aleksandra Bld., and Makedonska St., with Press Sq. Tourist potential of these spaces is very easy to observe even today, especially if one considers the fact that there is almost no visitor who omitted to notice that center of the city rests in a very special see of green. This is just a replicate of perception which rare travelers had in regard to Šumadija 
region and Belgrade in past centuries. In summertime, during the vegetation season (AprilOctober) visual features of Belgrade green, plant beauty by itself, their attractive irregular lines opposed to architectural uniformity and rectangular urban outline, their natural green color in contrast with metallic reflexes and dull concrete, and finally, their ecological character and efficiency represent the environmental value beyond compare. Everything that green of the "Krug Dvojke" in Belgrade represents and offers as tourist value is undisputable and truly highly appraised in tourist comments, weather stated while sojourning in Belgrade or after returning home. Nevertheless, as research shows, structural contents and abiotic/biotic details of central Belgrade green infrastructure may be considerably improved through introduction of certain number of new elements on main tourist tours for majority of group or individual visitations, as well as enhancing already existing architectonic forms (pools, fountains, sidewalls, slopes, lighting, benches, stands, plateaus, paths, fences, pergolas, stairs, children playgrounds, faucets, billboards, etc). Also, there are excellent opportunities for exhibiting massive sculptures that go extremely well with green grass in the background. Finally, particular hotel and catering potential of central Belgrade green infrastructure should not be forgotten. However, these objects should be reduced to small mobile restaurants and cafés in warm part of the year, made up of appropriate natural material - wood or possibly stone. In this way park space gains certain civilized dimension, reflecting our ability to organize our living space in accord with good traditional values and experiences of sophisticated world.

Analysis of researched area shows that there are a certain number of gray-green zones within the elements of central urban infrastructure, smaller and larger spaces where plant material is of inadequate volume and/or quality. The most significant among them are Railway Station Sq., Sava Pier, several shabby "pockets" of undeveloped open spaces in wider streets (Karadjordjeva St., Cara Dušana St., Kneza Miloša St., Takovska St., Narodnog Fronta St., Balkanska St.), and numerous small open spaces infront of public buildings and residential units. There is inadequate number of decorative plants, but ample open space for them.

Basic procedures for these zones' tourist value enhancement in fact include improvement of plant material quality, mostly and before all, trees. Old and large tree individuals are especially significant in the vicinity of resting places (platforms), cafés or restaurants, in both aesthetic and medical sense. That means that there is a need for professional and responsible reconstruction of green zones. Their intensive maintenance afterwards is also necessary, together with continuous innovation and modernization of special interest points within green spaces. These special points of interest would be presented to tourists not only by good tourist guides, but also by adequate information boards with short and interesting descriptions. Finally, zones with insufficient number of plant individuals must be replanted as soon as possible. Planting of individual trees, even in semi-pots if there is not adequate amount of open soil, is the first step in the right direction. Naturally, city inhabitants will also have direct benefit from such approach to central city organization, which is very significant by itself.

\section{Conclusions}

Research results provide sound basis for the formulation of several important conclusions. The most significant elements of ecological potential of central part of Belgrade commonly known as the "Krug Dvojke" are represented by various categories of green infrastructure: formal green spaces on one hand, and open, undeveloped spaces with certain number of existing plant individuals, on the other. 
Ecological, aesthetic, psychological and cultural functions of urban green are being supplemented by particular tourist potential, especially when green spaces are situated within standard tourist itinerary.

Classical green spaces of this area are represented by twelve different and relatively small urban parks, several tens of old and new street tree lines and groups of shade trees, few separate individuals of oldest street trees and a number of green spaces infront of public buildings. The highest tourist values among researched green spaces have Pionirski Park and Press Square (5.00), and the lowest the parks near the Faculty of Economics and Branko's Bridge (2.66). The most valuable are street tree lines in Kneza Miloša St., Skadarska St., and Knez Mihajlova St. The most valuable churchyard is the one around Voznesenjska Church, and the most valuable green space infront of the public building is the one of the Palace of Princess Ljubica.

The most significant semi-developed open spaces within the "Krug Dvojke" are Sava Pier and square infront of the Railway Station. Also, there is a large number of open spaces in wider streets and infront of numerous public buildings and other civil engineering objects. The most significant new unit of green infrastructure in this area is Park on Slavija Square, the green space of provisional character, developed on landfill of debris of former department store (socalled Mitić Hole).

The basis for tourist value enhancement of all of these spaces lies in achieving the topmost form and condition of existing plants, the task more important than architectural or civil engineering upgrading. Particular contribution to their better and more widespread share in urban tourist enterprise would certainly be introduction of seasonal restaurants and cafés, sculptures, and finally information boards which would offer visitors more detailed information about geographic, historic, ecological and cultural values of particular micro-sites within the most attractive green infrastructural elements of the "Krug Dvojke".

\section{References}

Anastasijević, N., Vratuša, V. (2001). Turizam i pejzažna arhitektura. Zbornik radova Ekološka istina, Donji Milanovac, 439-4.43

Anastasijević, N. (200o). Funkcionalnost Pionirskog parka u beogradu. Glasnik Šumarskog fakulteta, 82: 7-24

Anastasijević, N, Vratuša, V. (1999). Park u centru velikog grada - specifična turistička destinacija. Turizam, 3: 109-112

Anastasijević, N, Vratuša, V. (1998). Izmena osnovnih karakteristika izletišta i park šuma Beograda i njihovo neophodno prilagođavanje turističkim funkcijama. Turizam, 2/98: 97-100

Ceballos-Lascurain, H. (1991). Tourism, eco-tourism and protected areas. In Kusler (ed.): Ecotourism and Resource Conservation. Vol. 1. Eco-tourism and resource conservation project.

Fennell, D.A. (1999). Ecotourism: An Introduction. New York: Routledge.

Vratusha, V. and Anastasijevic, N. (2003). Serbian Urban Horticulture between Tradition and Future. First Symposium of Horticulture, Ohrid Macedonia, 16-20 October 2002, Symposium proceedings, Faculty of agriculture, Skopje, 469-473 